\title{
An Assessment on the Housing Auction Market in Selangor
}

\author{
Farah Eleena Zainudin1, Mariana Mohamed Osman², Siti Wahidah Muhamad Yusop1, Mansor Ibrahim³
}

\author{
1 Post Graduate Student, ${ }^{2}$ Associate. Professor. TPr. Dr., ${ }^{3}$ Professor Dato'TPr Dr. \\ Department of Urban and Regional Planning, Kulliyyah of Architecture and Environmental Design, \\ International Islamic University of Malaysia, Malaysia
}

leenaleen92@gmail.com, mariana@iium.edu.my, wahidahyusop1992@gmail.com, profmansor@iium.edu.my Tel: $017-2080224$

\begin{abstract}
The first auction legislation in Malaysia was enacted in the states of Penang and Malacca in 1906. The real estate market including auction market is considered an effective method in selling real estate properties (Chyi, 2015). Auction is one method in selling property in a quick way but this method is consider as force sales as most properties sold due to owner unable to pay the monthly mortgage to the bank. There are advantages of buying property in auction market where the buyer can get the property cheaper than market value and the property usually has a matured environment. The downside of purchasing an auction property is that the buyer is not allowed to view or inspect the inside of the property and sometimes the property is not vacant by the owner. The buyer need to conduct their own research first if they have the intention to buy auctioned property. Based on literatures, there are various considerations for buying auction properties such as the type of properties, the location, value, existing conditions, the existing facilities and infrastructure and many more. This aim of the study is to assess the issues and problems faced by buyers in housing auction market in Selangor. The objectives were to identify the preferred location among the respondents in selection their bidding units. It was found that among respondents, the most preferred location of auction properties was in Gombak. In term of issues and problem in buying auction properties, respondents claimed the issues are the long period of time in getting loan approved and released payment, the title and ownership issues, the units are still occupied by owner, the conditions of units and the overall cost that need to be prepare by buyers. It is hoped that this paper would guide decision maker and government in planning of the overall housing market in Malaysia as properties being auctioned is getting higher over time.
\end{abstract}

Keywords: Auction, Purchaser, Property, Selangor

eISSN: 2398-4287 @ 2019. The Authors. Published for AMER ABRA cE-Bs by e-International Publishing House, Ltd., UK. This is an open access article under the CC BYNC-ND license (http://creativecommons.org/licenses/by-nc-nd/4.0/). Peer-review under responsibility of AMER (Association of Malaysian Environment-Behaviour Researchers), ABRA (Association of Behavioural Researchers on Asians) and cE-Bs (Centre for Environment-Behaviour Studies), Faculty of Architecture, Planning \& Surveying, Universiti Teknologi MARA, Malaysia.

DOI: https://doi.org/10.21834/e-bpj.v4i12.1935

\subsection{Introduction}

Auction has become the dominant mechanism in selling property as it is a way of disposing of an asset by the bank in an open market for a possible higher price. Patrick (2007) defined auction market as a public sale of property where properties sold to the highest bidder, provided that reserve price has met. Moreover, the primary goal of selling property in an auction is to balances the supply and demand and to minimize the management costs of selling the property. The theory and practice of the property auction market need to be carefully elaborate as it will set the recommendations of the study. As in any property auction market, three dimensions should consider, which is the institution, the environment, and the agents' or bidder behavior. Doing research or study on an auction process is required when you want to bid, and at the fall of the gavel, the auction concluded as final. Nowadays, purchasing an auctioned property can be the right investment choice as these properties can obtained at lower market value without going through any longdrawn negotiations between seller and buyer. This study focused on the residential property auction market, generally in Selangor State. The underlying idea is to provide other options to the public in owning a house. The dynamic housing market that is flexible enough for people to own a home depending on their circumstances. The auction market should be accommodative in fulfilling

eISSN: 2398-4287 @ 2019. The Authors. Published for AMER ABRA cE-Bs by e-International Publishing House, Ltd., UK. This is an open access article under the CC BYNC-ND license (http://creativecommons.org/licenses/by-nc-nd/4.0/). Peer-review under responsibility of AMER (Association of Malaysian Environment-Behaviour Researchers), ABRA (Association of Behavioural Researchers on Asians) and cE-Bs (Centre for Environment-Behaviour Studies), Faculty of Architecture, Planning \& Surveying, Universiti Teknologi MARA, Malaysia.

DOI: https://doi.org/10.21834/e-bpj.v4i12.1935 
people's needs depending on their lifestyle as a different method in buying property. For example, during the bidding process, each potential buyer has set a limit on the maximum house price they want to buy. A well-functioning housing property auction market will help people effectively in the overall property market over the years. An efficient market maximizes the total profit obtained by all participating agents (Fudenberg and Tirole 1991).

\subsection{Research Objectives}

This study a descriptive analysis based on the observation of the housing property auction market in Selangor State. The results of this study can used to explain the issues and problems faced by successful bidders in the housing market. The study identified three objectives namely (1) To determine the desirable areas of auctioned housing property by the respondents in Selangor, (2) To study the factors influencing the respondents in buying the auctioned housing property, and (3) To identify the issues and problems in buying auctioned property. These objectives are essential as it provides a knowledge baseline on theory, mechanisms, and rules for the slot allocation problems.

\subsection{Literature Review}

Based on the literature review, research on auction housing property market in Malaysia is limited, especially on the factors influencing buyers to buy auction properties and the issues faced by these buyers, even though auctions process existed quite sometimes in Malaysia. Based on previous studies, mostly in the United States, it is found that a price discount for auctions sales was the main reason why auctions considered as an effective mechanism to dispose of distressed properties, following defaults on financings. Similarly, Ong et al. (2005) investigated the factors influencing auction outcomes of residential properties in Singapore found that the probability of an auction sale is likely to improve if auctioned property is a distress sale, the market is not in a recession, homogenous properties, located in central region and there is relatively high turnout. Current research identified that securing access to affordable housing for the urban poor and local people is critical for poverty eradication, institutional building, promoting good governance, and wealth distribution, which favors promoting auctioned market. In Malaysia, Chan et al. (2008) studied the characteristics of problematic residential properties left unsold after three consecutive auctions attempts in Kuala Lumpur and Selangor. However, the factors of auction success remain unidentified, particularly for Selangor. He identified the financing structure for housing financing needs to be significantly facilitated as it improves the accessibility of owning the property. Milligan et al. (2004), in the opinion that affordable housing means the sector is more responsive to the needs of households who do not have sufficient income to access adequate housing in the standard market without any assistance.

Consequently, they describe it as a housing arrangement that helps low-income households to obtain and pay for housing without facing undue financial difficulties. Thus, the residential property auction market can be as on medium for the people in owning a house. The UN-Habitat (2011b pg 9) also broadly defines affordable housing as adequate housing in terms of quality and location, which does not cost so much as to prohibit its occupants from meeting other necessary living costs or threatens their enjoyment of fundamental human rights. Therefore, if housing prices are high as compared to localities earners, the effect on the family to afford to own home or homeownership will lead to severe financial stress among the households (Z.A Hashim, 2010). This statement shows that with the auctioned market practice, people have a better chance of choosing their residential area based on their preferences of the location offered at a much lower price.

\subsection{Principles of Auction Market Theory favors in housing ownerships}

Auctions are models of markets in which products, services, or rights are bought and sold through a formal bidding process. The underlying definition that the core of auction theory is to make explicit the process is governing price formation. In auctions, the orders are competing with each other directly, at the same time, and on an equal footing. There is a mutual influence on the execution price among rules, and a single typical execution price per area. An increase in house prices affects the ability of a household to get mortgage loans (Reed, 2011). Auctions design, as a socially inspired method, can be seen as an area of crowdsourcing in management: obtaining needed services, ideas, or content by soliciting contributions from a large group of people, and especially from an online community, rather than from employees or suppliers. Most of the middle-income households disqualify for a mortgage on a median house price as they may have difficulty in making the monthly mortgage payments (Hanif \& Singaravello, 2010; Hashim, 2010).

\subsection{Research Methodology}

In this research, the data collected through primary and secondary data. Primary data gained through the distribution of questionnaires and interviews upon the target group with the total number of respondents is 100 in Selangor. Simple random sampling has been an approach in this research to select the respondents. The surveys and interviews from primary data interpreted into quantitative data via specific statistical software. The reason why the state of Selangor been chosen is that one of the states that have a higher level of urbanization with $91.4 \%$ in 2010, which rapidly urbanize in Malaysia after Kuala Lumpur and Putrajaya (Usman, 2011). Selangor state has been identified as the first developed state in Malaysia in the year 2005 due to the state that always ahead in various fields as an example of manufacturing, finance as well as transportation (Aziz, 2018). 
For the secondary data, the subject matter can be understood through reading from previous research, for instance, journals, books, dissertations, reports, and discussion. In the phase of theoretical study, the literature review needs to fulfill to find the research nap in the previous research. Quotation, paraphrasing, and summarizing are the technique being used to cite the previous researcher studies. The next phase is the stage of data analysis, where the data were analyzed using SPSS. The data have to be examined, analyzed, synthesized as well as translated into facts and figures. Thorough discussion and justification of descriptive data, an early hypothesis can be formed based on findings.

\subsection{Findings and Analysis}

\subsection{Respondents' Profile}

Table 1. Respondents' Profile

\begin{tabular}{|c|c|c|c|}
\hline \multicolumn{3}{|l|}{ Categories } & \multirow{2}{*}{$\begin{array}{l}\text { Frequency (f) } \\
51\end{array}$} \\
\hline \multirow{2}{*}{\multicolumn{2}{|c|}{ Gender }} & Male & \\
\hline & & female & 49 \\
\hline \multirow{4}{*}{\multicolumn{2}{|c|}{ Age }} & 20 and below & 0 \\
\hline & & $21-40$ & 36 \\
\hline & & $41-60$ & 54 \\
\hline & & 61 and above & 10 \\
\hline \multirow{3}{*}{\multicolumn{2}{|c|}{ Educational level }} & Primary level & 8 \\
\hline & & Secondary level & 45 \\
\hline & & Tertiary level & 47 \\
\hline \multirow{5}{*}{ Employment sector } & & Government sector & 24 \\
\hline & & Private sector & 20 \\
\hline & & Work independently & 38 \\
\hline & & Not working & 5 \\
\hline & & Pensioner & 13 \\
\hline \multirow{12}{*}{ Place of Origin } & \multirow{5}{*}{ Southern Region } & Negeri Sembilan & 5 \\
\hline & & Selangor & 54 \\
\hline & & Kuala Lumpur & 2 \\
\hline & & Johor & 7 \\
\hline & & Melaka & 1 \\
\hline & \multirow{4}{*}{ Northern Region } & Kedah & 3 \\
\hline & & Perak & 8 \\
\hline & & Perlis & 2 \\
\hline & & Penang & 2 \\
\hline & \multirow{3}{*}{ East Coast Region } & Kelantan & 3 \\
\hline & & Terengganu & 6 \\
\hline & & Pahang & 7 \\
\hline Total & & & 100 \\
\hline
\end{tabular}

Table 1 indicates the respondents' profile in Selangor. Based on the results, male respondents' (51\%) percentage is higher than female respondents $(49 \%)$. In terms of the age, there are four groups consist of age group below 20, 21- 40, 41- 60, and above 61. It 
is clearly that group $41-60$ is the dominant group, with $54 \%$. Next, the majority (47\%) of the respondents obtain a tertiary level of education, including diploma/ degree/ master/Ph.D. level. Followed by a secondary level (45\%). The respondents are mostly (38\%) work independently, as stated in table 1 , while the least percentage is $5 \%$ who is unemployed. Even though the respondents live in Selangor, however, their origin is from various countries. The result portrays the respondents come from 3 regions, which are in the southern region, the northern region as well as the east coast region. In the south part, mostly (54\%) are initially from Selangor while in the north part, dominantly with $8 \%$ of the respondents are come from Perak, and lastly, $7 \%$ are from Pahang on the east coast part.

\subsection{Preferred Location Of Auctioned- Property}

Table 2. Favourable Auctioned- Property Location Preferred by Respondents in Selangor

\begin{tabular}{|c|c|c|c|c|c|c|}
\hline \multirow{2}{*}{ Districts } & \multicolumn{5}{|c|}{ Preferences } & \multirow{2}{*}{ Total (\%) } \\
\hline & $1^{\text {st }}(\%)$ & $2^{\text {nd }}(\%)$ & $3^{\text {rd }}(\%)$ & $4^{\text {th }}(\%)$ & $5^{\text {th }}(\%)$ & \\
\hline Hulu Selangor & 21.8 & 16.6 & 22.2 & 19.4 & 20 & 100 \\
\hline Hulu Langat & 23.6 & 9.7 & 22.3 & 23.6 & 20.8 & 100 \\
\hline Klang & 18.2 & 19.4 & 30.5 & 22.2 & 9.7 & 100 \\
\hline Sepang & 20.8 & 19.4 & 19.5 & 23.7 & 16.6 & 100 \\
\hline Kuala Langat & 6.9 & 22.2 & 23.6 & 30.4 & 16.6 & 100 \\
\hline Gombak & 26 & 22.1 & 22.5 & 12.8 & 16.6 & 100 \\
\hline Petaling & 25 & 20.8 & 11.3 & 11 & 31.9 & 100 \\
\hline Kuala Selangor & 22.4 & 20.8 & 23.6 & 19.4 & 13.8 & 100 \\
\hline Sabak Bernam & 6.9 & 31.9 & 26.6 & 18 & 16.6 & 100 \\
\hline
\end{tabular}

Table 2 represents the district's preference by the respondents to select the place for auctioned- property in Selangor. The result indicates the most preferred location for buying auctioned- property is in the district of Gombak, with the most significant percentage voted by $26 \%$ of respondents. The second favorable district is in Sabak Bernam, with the rate of $31.9 \%$ of the respondents, while the third choice is the auctioned- property in Klang (30.5\%). The least preferred district for buying auctioned- property is in Kuala Langat and Petaling. The percentages show that $30.4 \%$ and $31.9 \%$ respectively agreed that both areas are unfavorable. Based on the previous study by Osman (2017), Petaling and Kuala Langat are the two districts at the highest and second highest of the affordability index in 2016 with index 5.7 and 4.9, respectively. By meaning, the house price is severely unaffordable and seriously unaffordable. Based on further interviewed among the respondents, the selection of area based on their familiarity of the area, their purposes of buying ie, whether for own staying or rent, the current market puller in the area (example MRT or LRT near to the unit) and the price of property offered during auctioned. These factors mostly influence their preferred locations.

\subsection{Factors Influencing The Reapondents' Decision to Buy Auctioned Property.}

Table 3. Factors Affecting the Auctioned- Property Biding

\begin{tabular}{|c|c|c|c|c|c|c|}
\hline \multirow{2}{*}{ Factors } & \multicolumn{5}{|c|}{ Preferences } & \multirow{2}{*}{ Total (\%) } \\
\hline & $1^{\text {st }}(\%)$ & $2^{\text {nd }}(\%)$ & $3^{\text {rd }}(\%)$ & $4^{\text {th }}(\%)$ & $5^{\text {th }}(\%)$ & \\
\hline Type of Property & 20.8 & 13.9 & 29 & 13.9 & 22.4 & 100 \\
\hline Type of Houses & 15.3 & 15.3 & 33.3 & 19.4 & 16.7 & 100 \\
\hline Location & 18 & 26.4 & 16.7 & 19.5 & 19.4 & 100 \\
\hline Investment Prospect & 20 & 19.4 & 11 & 33.6 & 16 & 100 \\
\hline Cost & 26 & 25 & 9.7 & 15.3 & 24 & 100 \\
\hline
\end{tabular}

In terms of the factors influencing their decision to bid, based on table 3, several factors were listed based on the literature review, and the respondents were asked to rank the factors influencing their decision to buy the auctioned property. Out of five listed factors, the majority of the respondents choose 'Cost' as the first preference factor with the percentage of $26 \%$, followed by location, where $26.4 \%$ of the respondents choose 'Location.' Meanwhile, the 'Type of House' as the third preference factor with the majority percentage of 
$33.3 \%$ of the respondents and with the percentage of $33.6 \%$, most of the respondents preferred 'Investment Prospect' as the fourth preference factor. Lastly, the respondents voted 'Type of Property' as the least factor affecting the biding the auctioned- property.

\subsection{Issues and Problems in Buying Auctioned- Property}

Table 4. Issues Highlighted by the Respondents in Selangor on Buying Auctioned- Property

\begin{tabular}{|c|c|c|c|c|c|c|c|}
\hline \multirow{2}{*}{ Issues } & \multicolumn{6}{|c|}{ Preferences } & \multirow{2}{*}{ Total (\%) } \\
\hline & $1^{\text {st }}(\%)$ & $2^{\text {nd }}(\%)$ & $3^{\text {rd }}(\%)$ & $4^{\text {th }}(\%)$ & $5^{\text {th }}(\%)$ & $6^{\text {th }}(\%)$ & \\
\hline Loan Release & 23.6 & 16.7 & 15.3 & 13.9 & 18 & 12.5 & 100 \\
\hline Property title and Ownership & 19.6 & 18 & 16.7 & 11 & 20.8 & 13.9 & 100 \\
\hline Loan Approval & 13.9 & 19.4 & 18 & 16.8 & 13.9 & 18 & 100 \\
\hline $\begin{array}{l}\text { Overall cost and deposit to be } \\
\text { ready }\end{array}$ & 15.3 & 13.9 & 22.2 & 19.4 & 12.5 & 16.7 & 100 \\
\hline Vacant or occupied unit & 16.7 & 18 & 15.3 & 20.8 & 13.9 & 15.3 & 100 \\
\hline Condition of the Property & 11 & 13.9 & 12.5 & 11 & 20.9 & 30.7 & 100 \\
\hline
\end{tabular}

In terms of issues and problems faced by bidder, based on table 4, six issues were listed, including the loan release, property ownership, loan approval, expenditure, vacant, and property condition. The result portrays 'Loan Release' is the main issue faced by the respondents, with the percentage of $23.6 \%$ of the respondents, followed by the issue on the 'Loan Approval,' the overall cost of buying the unit, the current occupancy of the unit and lastly the condition of the unit. The issue on loan release shows can take up a longer period compared to the duration given in the proclamation of sales, which usually stated 120 to 160 days period for the full settlement need to be done by the bidder. Based on literature and detail interviews, other complications or issues include learning that there's a caveat placed on the house by a third-party. Means that someone else who is interested in the property has filed a legal document on the house. This can hold up the sale for months and make a home loan on the property impossible to obtain or, finding out that the bank cannot extend the financing options that the buyer couldn't prefer due to the type of lease on the property.

\subsection{Conclusion and Recommendation}

Based on the analysis, the cost of buying auctioned property does affect the decision of buyers in purchasing auctioned property, and the delay in loan release identified as the main problem to the purchaser. In context to promoting homeownership vision of the country, there should be more information and guidance given by the government and housing stakeholders to the public about the auction market in general. Having in-depth knowledge of the process and background will help the purchaser to understand the risks in buying property in this niche market. Other than that, the bidding process for terms and conditions need to improve as the buyer need to understand and well prepared for the overall process of buying, especially before and after winning the bidding. Though complications can arise with any house sale, there could be more complications than usual if the buyer does not know all the risks of buying a property in an auctioned market. As identified, the issue of Loan Release shows that our banking system needs to revamp. As the banking system is the primary avenue for Malaysian households to access credits to finance a house purchase, thus, access to the banking system needs to be accommodative and dynamic to facilitate the buyers' needs in purchasing a house.

\section{References}

Aziz, A. (2018, August 1). Selangor, the Smart State. Retrieved from The Malay Reserve: https://themalaysianreserve.com/2019/08/01/selangor-the-smart-state-thestory-so-farl

Barton, H. \& Tsourou, C. (2000). Healthy Urban Planning. London: Spon.

Chan, W. S, Nasir, D. and Zahiriah, Y. (2008). Investigating the Characteristics of Problematic Residential Properties at Public Auction Sales Using Multiple Regression Analysis (MRA). University of Malaya and JS Valuers Reseach \& Consultancy Sdn Bhd, Malaysia.

Chyi, H. L. (2015). Determinants Of Auction Success And Auction Price Premium. Johor.

Dasimah Omar (2012). Determinant factors of neighbourhood quality. Planning Malaysia Journal of the Malaysian Institute of Planners, 10, 1-16.

Fudenberg, D. and J. Tirole. 1991. Game Theory. The MIT Press

Giffinger, R, Kramar, H. \& Haindl, G. (2008). The role of rankings in growing city competition. 11th European Urban Research Association (EURA) Conference, Milan, Italy, October $9-11,2008$. 
Kourtit, K. \& Nijkamp, P. (2012). Smart Cities in the Innovation Age. Innovation: The European Journal of Social Science Research, 25(2), 93-95.

Milligan V, Phibbs P, Fagan K and Gurran N (2004) A Practical Framework for Expanding Affordable Housing Services in Australia: Learning from Experience, Final Report No. 65, Australian Housing and Urban Research Institute

Mulligan, G., Carruthers, J. \& Cahill, M. (2004). Urban quality of life and public policy: A survey. In R. Capello \& P. Nijkamp (Eds.), Advances in urban economics (729802). Amsterdam: Elsevier Science B.

Ng, S. (2018, April 8). A step-by-step guide to buying auction properties. Retrieved from EdgeProp: https://www.edgeprop.my/content/1304739/step-step-guide-buyingauction-properties

Ong, S. E., Lusht, K. and Mak, C. Y. (2005). Factors Influencing Auction Outcomes: Bidder Turnout, Auction House and Market Conditions. Journal of Real Estate Research. 27, 177-191.

Patrick Bright, B. (2007). Property Auction Glossary. The Insider's Guide to Saving Thousands at Auction (pp.1-7). Australia: Brolga Publishing Pty Ltd.

Ramírez, Mario \& López, Adolfo \& Hernandez Iglesias, Cesareo \& Lavios, Juan \& Poza, David \& Ranieri, Andrea \& Herranz, Ricardo \& Lopez-Paredes, Adolfo. (2014). Review of Auction-Based Markets.

Usman Yaakob, T. M. (2011). Ninety Years of Urbanization in Malaysia:A Geographical Investigation of Its Trends and Characteristics. Georgetown.

Hashim, Z. A., 2010. House price and affordability in housing in Malaysia. Akademia 78, pp. 37-46

Reed, R., 2011. Housing affordability from a global perspective - a comparisonbetween housing demography in Australia and Germany.In 17th PRRES Pacific Rim Real Estate Society Conference Gold Coast, Australia, pp. 1-14.

Wan, N. A., Singaravelloo, K., and Hanif, N.R. 2010. "Challenge of middle income households to enter homeownership in Malaysia". APNHR Conference, Beijing, China August 21-22. 